\title{
A Complex Mosaic of High-Affinity Kainate Receptors in Rat Brain
}

\author{
W. Wisden and P. H. Seeburg \\ ZMBH, Universität Heidelberg, D-69 Heidelberg, Germany
}

The significance for CNS function of glutamate-gated cation channels that exhibit high-affinity kainate sites is not understood. Such receptors, which on dorsal root ganglia and in recombinant systems exhibit currents that rapidly desensitize to kainate application, have not been detected electrophysiologically in the brain. However, a comparison of the distribution of mRNAs encoding five glutamate receptor subunits exhibiting high-affinity kainate sites (GluR-5-GluR-7, KA-1, and KA-2) indicates that high-affinity kainate receptors are most likely involved in all central neuronal circuits of the rat brain. The KA-1 mRNA occurs mainly in the CA3 field of the hippocampus and dentate gyrus, with much lower amounts being found in inner cortical layers, cerebellar Purkinje cells, and white matter (e.g., corpus callosum and anterior commissure). The KA-2 gene is widely expressed in many neuronal nuclei including layers II-VI of neocortex, hippocampal pyramidal (CA1-CA3) and dentate granule cells, septal nuclei such as the bed nucleus of the stria terminalis, medial preoptic, suprachiasmatic, and ventral medial hypothalamic nuclei, dorsal raphe, locus coeruleus, and cerebellar granule cells. KA-2 mRNA is also found in the pineal gland. GluR-5 transcripts are in the cingulate and piriform cortex, the subiculum, lateral septal nuclei, anteroventral thalamus, suprachiasmatic nucleus, the tegmental nuclei, pontine nuclei, and Purkinje cells. GluR-6 mRNA is most abundant in cerebellar granule cells, with lower levels in caudate-putamen and the pyramidal cell layers and dentate granule cells of hippocampus. The GluR-7 gene is prominently expressed in the inner neocortical layers and some cells in layer II, subiculum, caudate-putamen, reticular thalamus, ventral medial hypothalamic nucleus, pontine nuclei, and in putative stellate/basket cells in the cerebellum. These findings suggest that a complex mosaic of receptor variants underlies the high-affinity kainate receptor in the vertebrate brain.

[Key words: kainate receptor, glutamate receptor, mRNA, in situ hybridization, cortex, cerebellum, hippocampus, reticular thalamus, pineal gland, septum, suprachiasmatic nucleus]

Received Nov. 16, 1992; revised Feb. 12, 1993; accepted Feb. 25, 1993.

We thank Dr David Laurie and the two anonymous reviewers for comments on the manuscript and Dr. U. Gretherath for help in identifying GluR-5-expressing cells. This work was supported by BMFT Grant BCT $364 \mathrm{Az}$ to P.H.S.

Correspondence should be addressed to W. Wisden, Division of Neurobiology, Laboratory of Molecular Biology, MRC Center, Hills Road, Cambridge CB2 2QH, England.

Copyright (C) 1993 Society for Neuroscience $0270-6474 / 93 / 133582-17 \$ 05.00 / 0$
Prior to the pioneering isolation of the first ionotropic glutamate receptor subunits (Gregor et al., 1989; Hollmann et al., 1989; Wada et al., 1989), vertebrate brain excitatory amino acid (EAA) receptors were divided on the basis of binding selectivity of certain synthetic agonists into the well-known trilogy of NMDA, $\alpha$-amino-3-hydroxy-5-methyl-isoxazole-4-propionate (AMPA), and high-affinity kainate subtypes (reviewed by Monaghan et al., 1989; Young and Fagg, 1990). In addition, a wealth of literature suggested that AMPA and kainate sites were on the same protein even though the anatomical distribution of the highaffinity $\left(K_{d}=5\right.$ and $\left.50 \mathrm{~nm}\right)$ kainate sites differed from that of the AMPA sites (reviewed in Henley et al., 1989; Patneau and Mayer, 1991). Subsequent cloning studies demonstrated that AMPA (as a partial agonist) and kainate (as a full agonist) both activated channels built from GluR-A-GluR-D (GluR-1-GluR4) subunits that constitute a high-affinity AMPA/low-affinity (mM) kainate receptor subtype (Boulter et al., 1990; Keinänen et al., 1990; Nakanishi et al., 1990; Gasic and Hollmann, 1992; Sommer and Seeburg, 1992). On recombinant AMPA receptor channels, kainate activates a large nondesensitizing current of the type seen when kainate is applied to CNS neurons (Patneau and Mayer, 1991; Jonas and Sakmann, 1992). This AMPA/lowaffinity kainate class of receptor (also referred to as the "AMPA receptor") probably serves as a "general purpose" depolarizing receptor at many central synapses and mediates fast excitatory neurotransmission. Similarly, the chicken kainate-binding protein, whose expression is restricted to cerebellar Bergmann glia (Gregor et al., 1989; Somogyi et al., 1990), has a low $\left(K_{d}, 0.6\right.$ mM) affinity for kainate (Henley and Barnard, 1991), and may serve as a functional homolog of the calcium-permeable AMPA low-affinity kainate receptors comprising the GluR-A $A_{\text {Flip }}$ and GluR-D $D_{\text {Flip }}$ subunits found on rodent Bergmann glia (Burnashev el al., 1992; Müller et al., 1992).

In the PNS, dorsal root ganglion cells carry an ionotropic high-affinity kainate receptor (Agrawal and Evans, 1986; Huettner, 1990), but the rapidly desensitizing current characteristics of this channel have not been detectable in the brain. Hence, the contribution of the high-affinity kainate "receptor" to EAA function in the CNS has remained obscure. High-affinity kainate receptors are often invoked to explain kainate-mediated toxicity, since kainic acid, and its close structural relative domoate, are very potent excitotoxins for certain populations of neurons. Hippocampal CA3 pyramidal cells, which have an extremely high density of ${ }^{3} \mathrm{H}$-kainate sites, are particularly sensitive (e.g., Nadler et al., 1978; reviewed by Coyle, 1983). However, neuronal vulnerability to kainate is only partially correlated with the distribution of high-affinity kainate sites determined by autoradiography (Foster et al., 1981; Monaghan and Cotman, 1982; 
Unnerstall and Wamsley, 1983; Miller et al., 1990), and it can be argued that kainate-mediated toxicity reflects the action of AMPA/low-affinity kainate receptor subtypes that are abundant in the same brain regions. A further complication is that to kill neurons effectively, kainate often requires the integrity of excitatory afferents (reviewed by Coyle, 1983). This suggests an indirect action, the mechanism of which has promoted considerable controversy (Ferkany et al., 1982; Coyle, 1983; Garthwaite and Garthwaite, 1983; Poli et al., 1985; Pocock et al., 1988). Collectively, these arguments precipitated a loss of faith in the CNS high-affinity kainate site-which became "a binding site in search of a function" (Young and Fagg, 1990).

The recent cloning of specific high-affinity kainate receptor (also referred to as the "kainate receptor") subunits has promoted a reassessment. It now seems that this site may well be relevant to central EAA synaptic transmission, and that it is also functionally heterogeneous. Currently, rodent high-affinity kainate receptors can be constructed from two branches of the EAA receptor subunit gene family; KA-1 and KA-2 (Werner et al., 1991; Herb et al., 1992; Sakimura et al., 1992) and GluR-5 (Bettler et al., 1990; Sommer et al., 1992), GluR-6 (Egebjerg et al., 1991), and GluR-7 (Bettler et al., 1992; Lomeli et al., 1992). The mRNAs encoding the GluR-5 and GluR- 6 subunits can exist in two alternative forms, either coding for an arginine (R) or glutamine $(Q)$ residue in a functionally critical region of a putative channel-forming segment. This difference is specified by RNA editing (Sommer et al., 1991; Sommer and Seeburg, 1992). Two other subunits that are related in sequence ( $\delta 1$ and $\delta 2)$ apparently do not function as kainate receptors and remain "orphans" (Yamazaki et al., 1992; Lomeli et al., 1993).

Unfortunately, there is as yet no simple and concise model for the construction of high-affinity kainate receptors in native brain membranes. The affinities of the two classes (KA and GluR-5-GluR-7) of subunits for kainate average $5 \mathrm{~nm}$ and 50 $\mathrm{nM}$, respectively, and these may reflect the two high-affinity kainate sites found on native brain membranes (London and Coyle, 1979; Unnerstall and Wamsley, 1983; Hampson et al., 1987; Monaghan and Anderson, 1991). The GluR-5(Q) and GluR-6 subunits (but not GluR-7) can form functional desensitizing kainate-gated channels in the homomeric configuration (Ejebgerg et al., 1991; Bettler et al., 1992; Lomeli et al., 1992; Sommer et al., 1992). The homomeric GluR-5(Q) channel functionally resembles the native kainate receptor found on dorsal root ganglia cells (Huettner, 1990; Sommer et al., 1992), suggesting that at least some of these subunits may occur naturally as homomeric channels. In contrast to the closely related GluR-6 subunit, GluR-5(Q) receptor channels can be gated by AMPA, a feature also described for the dorsal root ganglion receptors (Huettner, 1990; Egebjerg et al., 1991; Sommer et al., 1992). A considerable complication is that some high-affinity kainate receptor configurations found in vivo, especially involving edited forms of the GluR-5 and GluR-6 subunits, may be permeable to $\mathrm{Ca}^{2+}$ ions (Pruss et al., 1992; Köhler et al., 1993).

The recombinant KA-1 and KA-2 subunits cannot form detectable homomeric ligand-gated ion channels. However, when these KA subunits are coexpressed with GluR-5 or GluR-6 subunits, channels with new emergent properties are generated, in terms of desensitization to kainate (Herb et al., 1992; Sakimura et al., 1992). Furthermore, AMPA can elicit a nondesensitizing current component on KA-2/GluR-6 combinations (Herb et al., 1992; Sakimura et al., 1992), although as mentioned above, homomeric GluR-6 receptors are not sensitive to AMPA
(Egebjerg et al., 1991; Herb et al., 1992). Thus, there maybe two types of ionotropic non-NMDA receptors: high-affinity AMPA/low-affinity kainate and high-affinity kainate/low-affinity AMPA receptors. These two classes of receptors also differ in their rate of desensitization to AMPA and kainate.

In order to examine possible partnership relations in the highaffinity kainate receptor series, we present a systematic comparison of the gene expression patterns of the five currently known subunit members in the adult rat brain. Although descriptions of the mRNA distributions for a limited number of brain regions in rat (KA-1, KA-2: Werner et al., 1991; Herb et al., 1992; GluR-5, GluR-7: Bettler et al., 1990, 1992, Lomeli et al., 1992) and mouse (GluR-6: Egebjerg et al., 1991) have been previously determined with combinations of cRNA (for GluR-5-GluR-7) and oligonucleotide probes (for KA-1, KA-2, and GluR-7), it is valuable to have a systematic and detailed comparison performed using one species and one method. This study may additionally serve as a reference for future immunocytochemical studies such as those undertaken for the AMPA/ low-affinity kainate receptor subunits (Blackstone et al., 1992; Martin et al., 1992; Petralia and Wenthold, 1992; Wenthold et al., 1992).

\section{Materials and Methods}

In situ hybridization using adult (6-month-old) male Wistar rat brains was performed as previously described (Wisden et al., 1991) using oligodeoxynucleotide probes tailed at their $3^{\prime}$ end with $\alpha^{35}$ S-dATP (1200 $\mathrm{Ci} / \mathrm{mmol}$; New England Nuclear) and terminal transferase (Boehringer Mannheim), with a 30:1 molar ratio of $\alpha^{35}$ S-dATP:oligonucleotide. The sections were hybridized in a "minimalist" buffer containing only $50 \%$ formamide, $4 \times$ saline-sodium citrate (SSC), $10 \%$ dextran sulfate at $42^{\circ} \mathrm{C}$ (probe concentration, $1 \mathrm{pg} / \mathrm{ml}$ ) and washed with $1 \times \mathrm{SSC}$ at $60^{\circ} \mathrm{C}$. After dehydration, sections were exposed to $x$-ray film (for 6 weeks) or dipped in Ilford $\mathrm{K} 5$ emulsion (for 12 weeks). After developing, the sections were counterstained with thionin. The atlas of Paxinos and Watson (1986) was used to identify and confirm rat brain structures.

The sequences of the oligonucleotide probes were as follows: GluR5, 5'-CCCGGGTTGGTTCCATTGGGCTTCCGGTAAAGGATGCTAATGCCC-3' (oligonucleotide O1-4 in Sommer et al., 1991); GluR-6, 5'-ACTAAACCTGGCTATGACAAAGAGCACACAACTGACACCCAAGTA-3', complementary to codons for mature rat GluR-6 residues 540-554 (EMBL Genbank number Z1 1715); GluR-7, 5'-ACTGGGGTTGGTGCCATTGGGTTTTCGATATAAGATGCTCACTCCG-3' and 5'-ATTCTCCACCACCTCAGAGCCGGGGTTGCAGGGGTGGGCATCATA-3' [all images are illustrated with the second listed probe (Lomeli et al., 1992)]; KA-1, $5^{\prime}$-CTTGTAGTTGAACCGTAGGATCTCAGCGAACTCCTTGAGCATGTC-3', 5'-TAGCCCGGTCTGCGTCCCATATGAACTCTGTAAAGAATACTA-3', and 5'-GTTGACCAGGAGATTACACCGGCCCTGTGCACAAGGATGTGGACT-3' [all images in this article are illustrated with the first oligonucleotide (Werner et al., 1991)]; KA-2, 5'-GTTCTCCAGGATATGGGGACGCGCCCG-

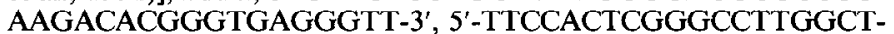
GGGACCTCGATGATCCCATTGATCTG-3', and 5'-GCCGGGCTTGGACTTCACCAGAAACTGAAGGCAAAATCGC- $3^{\prime}$ [all images are illustrated with the first oligonucleotide (Herb et al., 1992)]. Controls for specificity included the use of oligonucleotides recognizing different parts of the mRNA (see above) and the use of competition hybridizations in which, in addition to the labeled probe, the hybridization buffer contained a 100 -fold excess of unlabeled probe, resulting in virtually blank autoradiographs. As a further confirmation of probe specificity, several of the subunit-specific oligonucleotide probes (GluR-5-GluR7) gave patterns identical or very similar to that obtained using cRNA probes (Bettler et al., 1990, 1992; Egebjerg et al., 1991).

\section{Results}

Using specific oligonucleotide probes, we examined the regional pattern of expression of the five functionally identified highaffinity kainate receptor subunit genes (GluR-5-GluR-7, KA-1, and $\mathrm{KA}-2$ ) in a series of coronal sections of the adult rat brain. 


\begin{tabular}{|c|c|c|c|c|c|}
\hline Brain region & GluR-5 & GluR-6 & GluR-7 & $\mathrm{KA}-1$ & KA-2 \\
\hline \multicolumn{6}{|l|}{ Neocortex } \\
\hline Layer II & + & + & $(+)$ & $(+)$ & +++ \\
\hline Layer VI & + & + & +++ & + & +++ \\
\hline Cingulate cortex & ++ & $(+)$ & +++ & + & +++ \\
\hline Pyriform cortex & ++++ & +++ & $(+)$ & + & ++++ \\
\hline \multicolumn{6}{|l|}{ Hippocampus } \\
\hline Dentate gyrus & 0 & ++ & $+t$ & +++ & ++++ \\
\hline CA1 pyramidal & $(+)$ & + & $(+)$ & $(+)$ & ++++ \\
\hline CA3 pyramidal & 0 & + & $(+)$ & ++++ & +++ \\
\hline \multicolumn{6}{|l|}{ Striatum } \\
\hline Caudate-putamen & $(+)$ & + & ++ & $(+)$ & +++ \\
\hline Globus pallidus & $(+)$ & 0 & $(+)$ & + & $(+)$ \\
\hline \multicolumn{6}{|l|}{ Septum } \\
\hline Bed nucleus stria terminalis & +++ & + & + & $(+)$ & +++ \\
\hline Lateral septum & ++ & $(+)$ & 11 & $(+)$ & ++ \\
\hline Medial septum & $(+)$ & $(+)$ & ++ & + & ++ \\
\hline Medial habenula & 0 & 0 & $(+)$ & + & +++ \\
\hline \multicolumn{6}{|l|}{ Thalamus } \\
\hline Reticular nucleus & 0 & $(+)$ & +++ & $(+)$ & $(+)$ \\
\hline Ventral posterior & 0 & 0 & 0 & 0 & 0 \\
\hline Anterior ventral & +++ & 0 & ++ & $(+)$ & ++ \\
\hline \multicolumn{6}{|l|}{ Hypothalamus } \\
\hline Medial preoptic & + & $(+)$ & + & + & $1+$ \\
\hline Dorsal medial & + & 0 & $(+)$ & $(+)$ & ++ \\
\hline Ventral medial & + & 0 & ++ & $(+)$ & + \\
\hline Suprachiasmatic & ++++ & 0 & + & $(+)$ & ++ \\
\hline \multicolumn{6}{|l|}{ Hindbrain } \\
\hline Dorsal Raphe & 0 & + & + & + & ++ \\
\hline Pontine nucleus & +++ & 0 & ++ & + & $(+)$ \\
\hline Locus coeruleus & 0 & $(+)$ & 0 & $(+)$ & +++ \\
\hline Rhabdoid nucleus & ++++ & $(+)$ & $(+)$ & + & + \\
\hline \multicolumn{6}{|l|}{ Cerebellum } \\
\hline Stellate/basket & 0 & 0 & ++ & 0 & 0 \\
\hline Purkinje cell layer & ++ & 0 & 0 & + & 0 \\
\hline Granule cells & 0 & +++ & 0 & 0 & +++ \\
\hline Corpus callosum & 0 & $(+)$ & 0 & + & 0 \\
\hline Pineal gland & 0 & 0 & 0 & 0 & +++ \\
\hline
\end{tabular}

In situ hybridization signals obtained with ${ }^{35} \mathrm{~S}$-labeled oligonucleotide probes on serial sections were assessed (from a mixture of $X$-ray film and dipped sections on three animals) as ++++ , very abundant; +++ , abundant; ++ , moderate; + , detectable; $(+)$, borderline detectability; 0 , no expression.

The results compiled from the figures and unpublished data are summarized in Table 1.

\section{Anterior olfactory nucleus}

The anterior olfactory nucleus, previously highlighted because of its strong differential expression of the AMPA receptor Flip and Flop subunit mRNAs (Sommer et al., 1990), has been described as a "rather undifferentiated grey substance immediately behind the olfactory bulb" (Switzer et al., 1985). It may represent a primitive part of the allocortex. The dorsal anterior olfactory nucleus expresses all five subunits mRNAs, but particularly those of GluR-7 and KA-2 (Fig. $1 E, I$ ).

\section{Neocortex}

The most abundant high-affinity kainate receptor transcript in the cortex is that of KA-2 (Figs. $1 I, J ; 2 I, J ; 3 I, J)$. This gene is expressed in all cortical layers, although it is weaker in layer IV (middle cortical laminae). Numerous cortical cells express the KA-2 gene, as shown by low-power dark-field optics (Fig. 4A). There is no KA-2 expression in the cell-poor layer I (Fig. B). The next most abundant cortical transcript is that of GluR-7 (Figs. $1 E, F ; 2 E, F ; 3 E, F)$. The strong, but confined, expression of the GluR-7 gene to the inncr cortical layers (IV, V, VI) is a striking feature. At the level of cellular resolution in the deep 

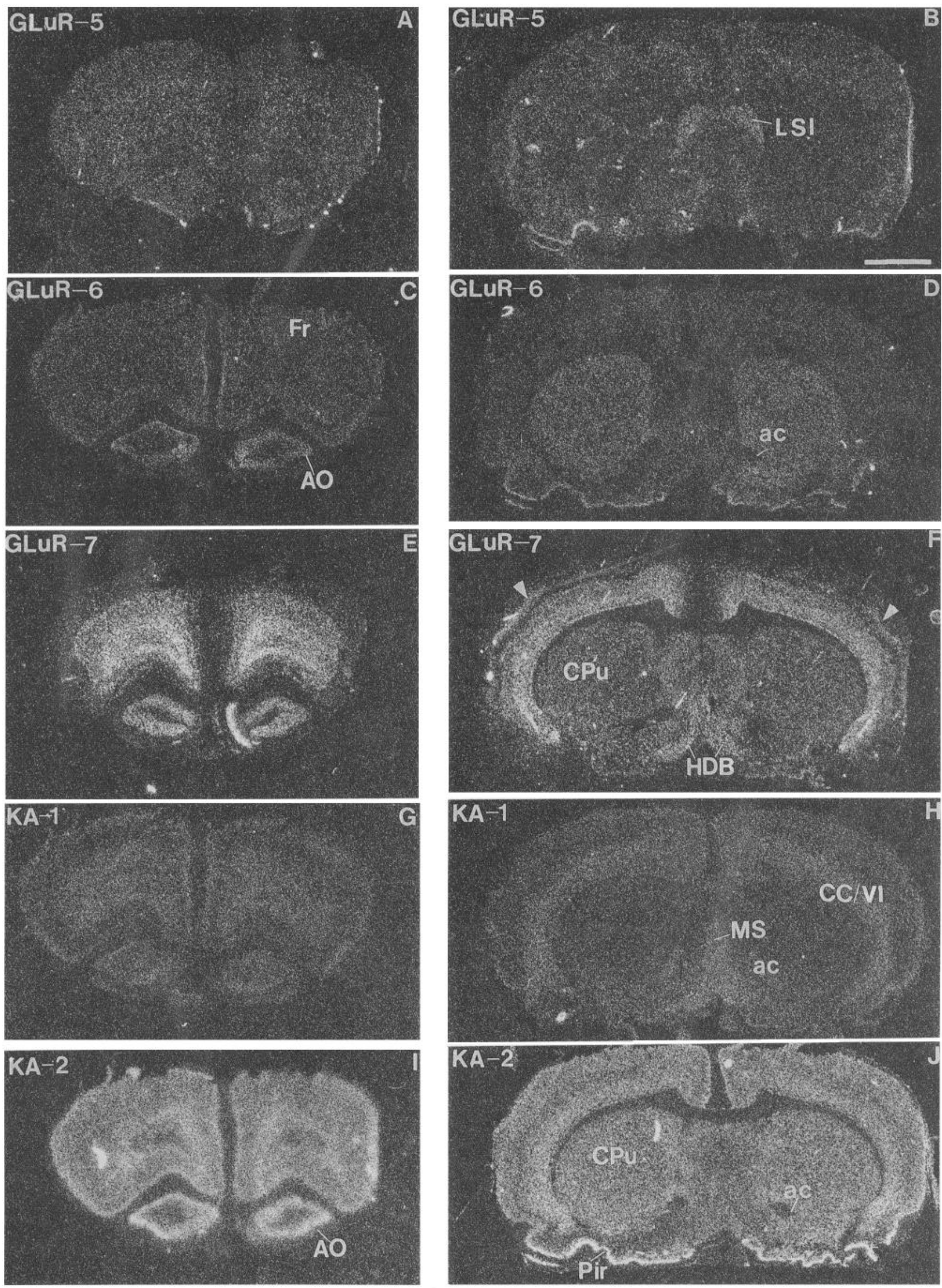

Figure 1. Distribution of high-affinity kainate receptor mRNAs in coronal sections at level of anterior olfactory nucleus (left column) and caudateputamen (right column). Arrowheads in $F$ indicate putative layer III cells expressing the GluR-7 gene. See Appendix for abbreviations. Scale bar, $3.2 \mathrm{~mm}$. 


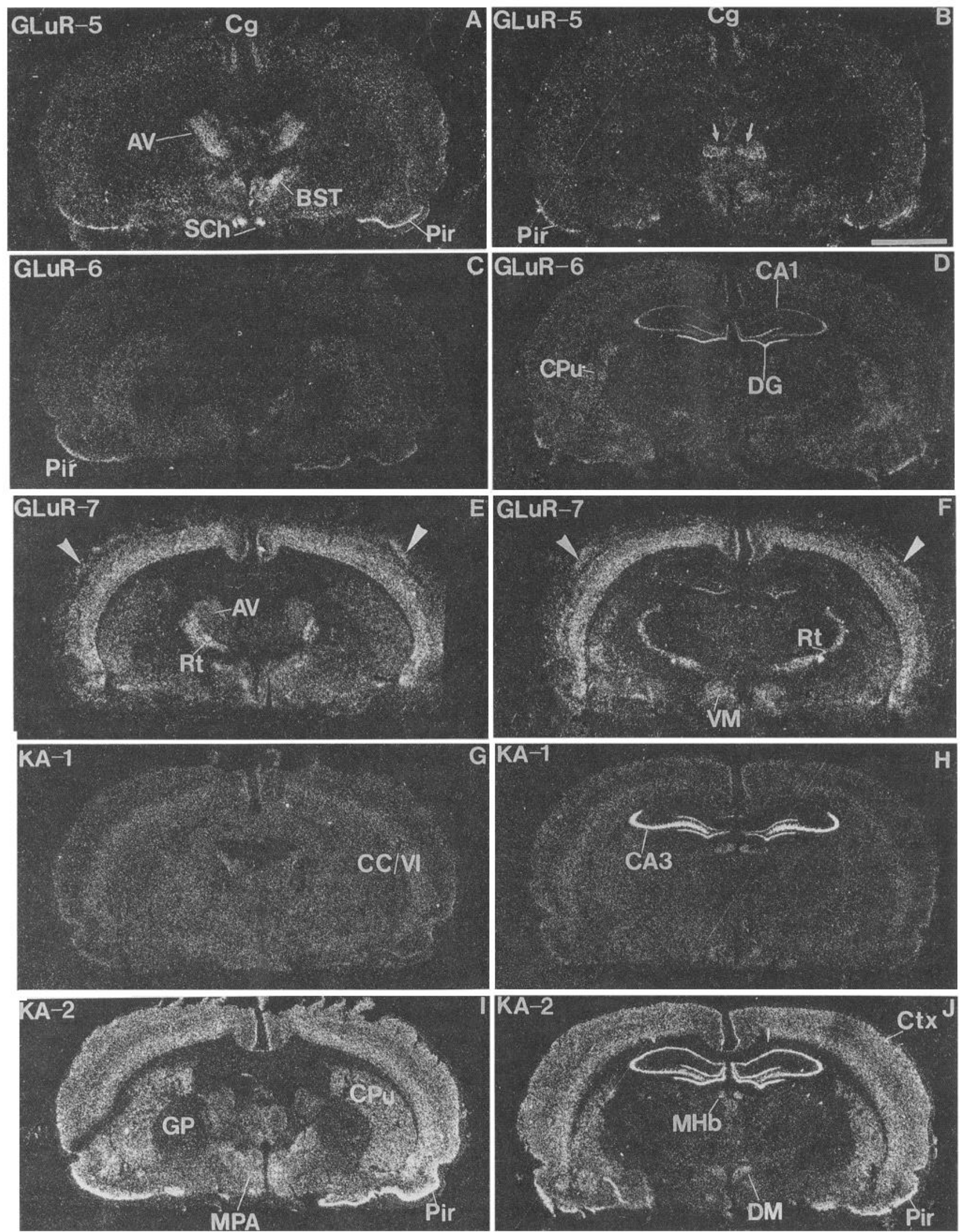

Figure 2. Distribution of high-affinity kainate receptor mRNAs in coronal sections at level of suprachiasmatic nucleus (left column) and reticular thalamic nucleus (right column). Arrows in $B$ indicate a nucleus expressing the GluR-5 gene, but the exact identity of this nucleus could not be confidently determined. Arrowheads in $E$ and $F$ indicate putative layer III cells expressing the GluR-7 gene. See Appendix for abbreviations. Scale bar, $3.2 \mathrm{~mm}$. 
cortical layers, the GluR-7 signal is confined to silver grains decorating large paler-stained cells, probably corresponding to pyramidal cells (Fig. 5C). Expression in layers II/III is minimal. Nevertheless, there are a few neurons that are intensely labeled in the outer cortical laminae as detected by dipping in photographic emulsion (Figs. $4 C, 5 B$ ). Further, as noted previously (Lomeli et al., 1992), certain parts of the cortex show an intense but thin sublayer of expression, possibly in layer III (indicated by arrowheads in Figs. $1 F, 2 E, F)$.

Compared to the levels of expression of the KA-2 and GluR-7 genes, the relative proportion of mRNAs encoding the other three subunits in cortex is low. However in the posterior cingulate cortex, GluR-5 and GluR- 6 mRNAs are much more abundant than in the surrounding cortical areas (Figs. $2 A-D$, $3 A, C$ ). In contrast, the anterior cingulate cortex does not appear to contain elevated levels of GluR-5-GluR-7 transcripts. At the level of $\mathrm{x}$-ray film analysis, GluR-5 mRNA is present in a number of scattered cells, as indicated by a very punctate autoradiographic image unique to the GluR-5 probes (e.g., Figs. $1 A$, $2 A$ ). This punctate pattern can be similarly seen in the $\mathrm{x}$-ray film autoradiographs of Bettler et al. (1990). This is confirmed by examination of emulsion-coated slides: occasional clusters of grains are seen over cell bodies - but most cells are not labeled (Fig. 5A). In contrast, GluR-6 mRNA is present at weak and uniformly low levels, and in our hands gave a signal too low to be detected with photographic emulsion. The KA-1 gene is expressed weakly in layers II and V/VI extending into the corpus callosum (see White matter tracts, below, and Figs. $1 G, H ; 2 G, H$; $3 G ; 8 B)$.

\section{Piriform cortex}

The piriform (primary olfactory) cortex expresses all five kainate receptor subunit genes, although levels of GluR-7 and KA-1 mRNA are very low (e.g., see Figs. $1 B, D, F, H, J ; 2 A-J)$. The strongest subunit expression in the piriform cortex is GluR-5, GluR-6, and KA-2.

\section{Hippocampal formation}

The five high-affinity kainate subunit genes are differentially cxpressed in the hippocampal formation. By far the most abundant mRNAs in the hippocampus proper are KA-1 and KA-2 (Figs. $2 H, J ; 3 G, I$ ). The KA-2 gene is expressed equiabundantly in all pyramidal cells (CA1 through to CA3), and in the dentate granule cells (Figs. 2J, 3I). The substantially elevated levels of KA-1 mRNA in the CA3 pyramidal cells, in contrast to a near absence in those of CAl (Figs. $2 H, 3 G$ ), has been described previously (Werner et al., 1991). In the mouse brain, GluR-6 mRNA is present in a clear CA3 > CAl expression gradient (Egebjerg et al., 1991). However, this is not very striking in the case of GluR-6 gene expression in the rat hippocampus (Fig. $2 D$ ). For the CA pyramidal cells, the amount of GluR-6 mRNA is quite low compared to levels of the KA subunit mRNAs. Cells in CA3 do express more GluR- 6 mRNA than in CA1 pyramidal cells (Fig. $3 C$ ), but this is not as prominent as for KA-1.

GluR-5 and GluR-7 have a similar expression pattern in the hippocampal formation; both of these subunit mRNAs are virtually absent from the CA pyramidal cell layers (Figs. $2 B, F$; $3 A, E$ ). However, they are present at high levels in the pyramidal cell layer of the subiculum (Fig. $3 A, B, E, F$ ). GluR-5 and GluR-7 mRNAs are particularly elevated in the presubiculum. KA-1 and KA-2 mRNAs are also present in the subiculum but are not elevated in the pyramidal cell layer in the manner of GluR-5 and GluR-7. At the level of x-ray film resolution, the GluR-5 mRNA is completely absent from the hippocampus proper (Figs. $2 B, 3 A$ ), whereas GluR-7 mRNA is present in dentate granule cells (Figs. $2 F, 3 E$ ), but is also found in occasional cells in the CA pyramidal layers (see Lomeli et al., 1992), and in scattered putative interneurons in the stratum oriens (not shown). In more rostral planes of section of the dentate gyrus, GluR-7 mRNA has a tendency to be concentrated in the ventral blade (Fig. $2 F$ ).

\section{Basal ganglia}

The caudate-putamen and nucleus accumbens contain GluR-6, GluR-7, and KA-2 mRNAs (Figs. $1 D, F, J ; 2 C-F, I, J)$. A very weak KA-1 signal is also detectable in the caudate-putamen. The globus pallidus contains occasional cells expressing GluR7, KA-1, and KA-2 (not shown). Any striasomal organization of subunit mRNAs was not examined.

\section{Septum}

Of the four high-affinity kainate receptor genes (GluR-5, GluR$7, \mathrm{KA}-1$, and $\mathrm{KA}-2$ ) that are significantly expressed in the septal areas examined here, the GluR-5 mRNA has the most restricted expression, being mainly in the dorsal lateral and intermediate lateral septal nuclei (Fig. $1 B$ ). Some GluR-5 expression is also found in the diagonal band. The GluR-7 and KA-2 transcripts are more widespread and codistributed (Fig. $1 F . J$ ). GluR-6 mRNA is not abundant in any of the septal areas examined (Fig. 1D). GluR-7, KA-1, and KA-2 mRNAs are all present in the medial septal nucleus/nucleus of the diagonal band (Fig. $1 F, H, J)$. Three subunit genes (GluR-5, GluR-7, and KA-2) are expressed in the bed nucleus of the stria terminalis, with GluR-5 expression being highlighted, because of the lack of expression of this gene in the surrounding nuclei (Fig. $2 A, E, I$ ).

\section{Epithalamus-medial habenula}

The medial habenula expresses a limited subset of subunits, that is, KA-1, KA-2, and to some extent GluR-7 (Fig. $2 F, H, J$ ).

\section{Thalamus}

The thalamus provides a further clear example of the heterogeneous nature of high-affinity kainate receptor subunit gene expression. Within this structure, spatial mRNA mismatches are extreme. The GluR-5 gene expression is particularly interesting, with prominent expression being found in numerous small subnuclei, symmetrically distributed along the midline (see arrows in Figs. $2 B, 3 A$ ). With the exception of the anteroventral nucleus (Fig. $2 A$ ), none of these GluR-5-expressing thalamic nuclei could be confidently identified, and they appear to be subdivisions of larger nuclei. Although low levels of KA-2 mRNA could also be present in some of these nuclei (Figs. 2I, $3 n$, especially in the anteroventral nucleus, this thalamic pattern is strikingly unique to GluR-5 (Fig. $3 A$ ).

Another obvious mismatch is the reticular thalamic nucleus, which contains high levels of GluR-7 mRNA (Fig. $2 F$; see also Bettler et al., 1992; Lomeli et al., 1992), with only weakly detectable signals for GluR-6 and KA-2. The GluR-6, and KA-1 probes give low diffuse signals throughout the thalamus.

\section{Hypothalamus}

The hypothalamus similarly exhibits pronounced mismatches for kainate receptor subunit mRNA expression. For example, only KA-2 mRNA is found at elevated levels in the dorsal 


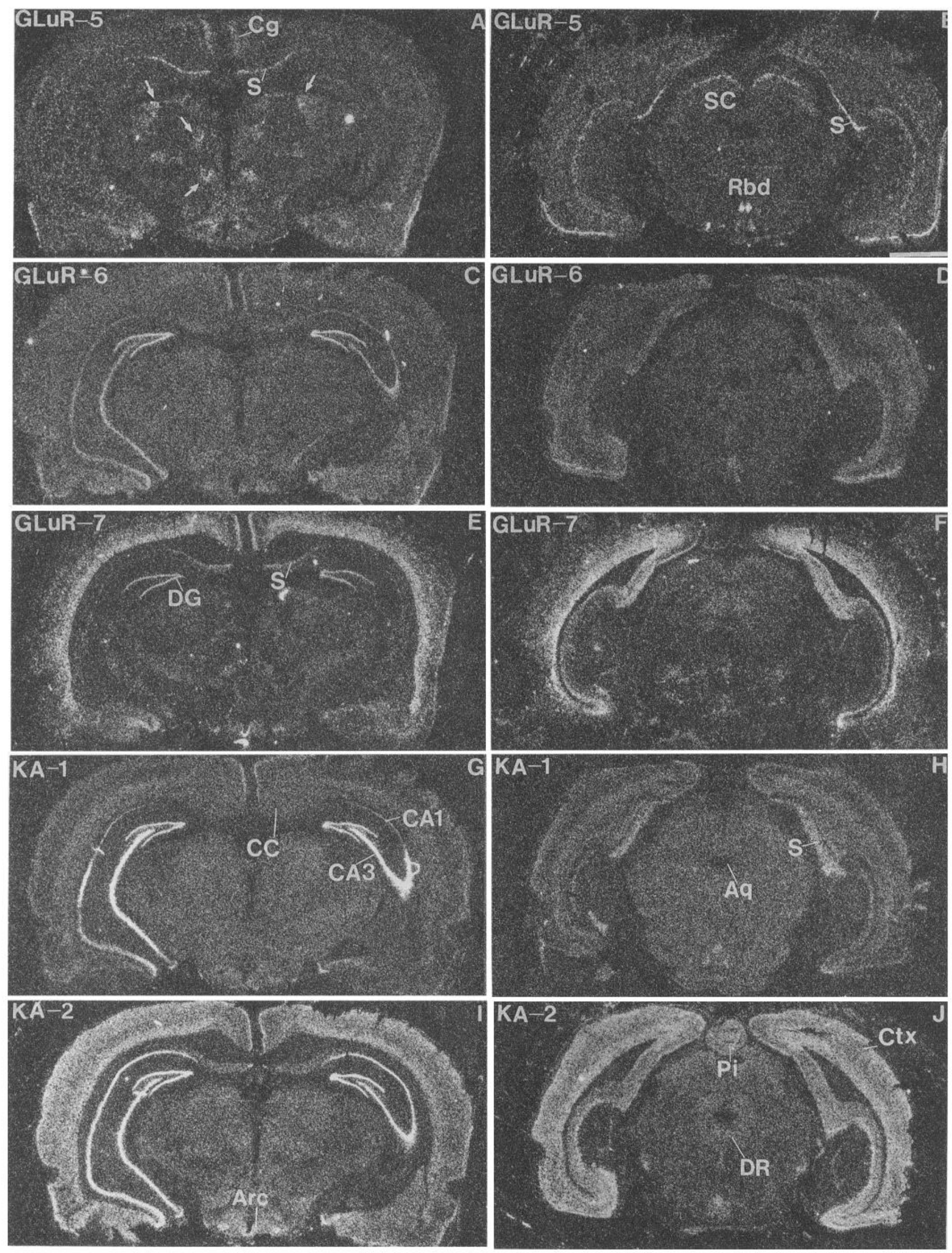



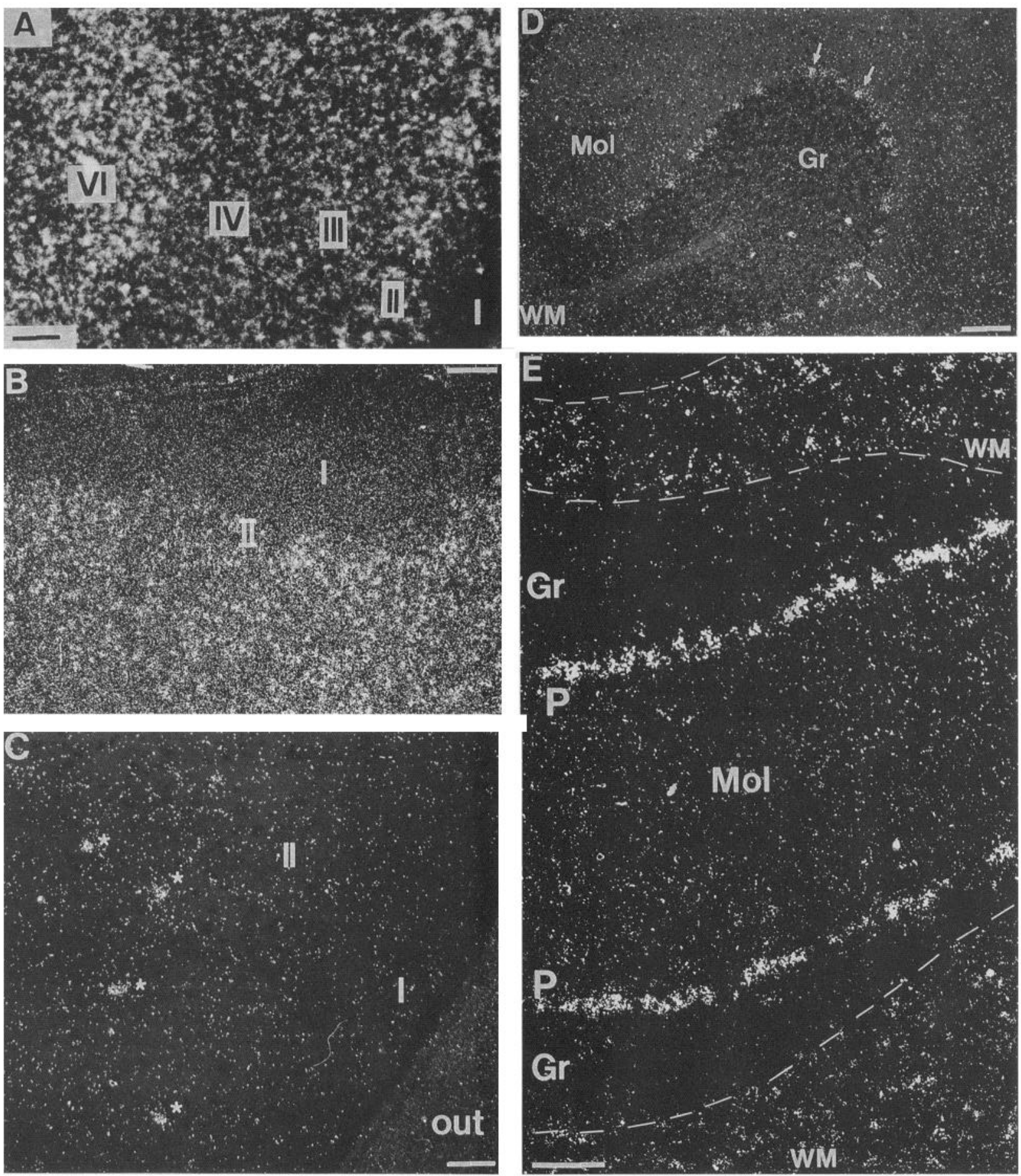

Figure 4. Dark-field low-power photomicrographs showing distribution of KA-2-expressing cells in all layers of entorhinal cortex $(A)$; KA-2expressing cells in layer II of neocortex $(B)$; GluR-7-expressing cells in layer II of neocortex ( $C$; indicated by asterisks; out refers to the outside of the brain); Purkinje cells (examples indicated by arrows) expressing the GluR-5 gene $(D)$; and KA-1 mRNA in the cerebellum $(E)$. Expression is seen in Purkinje cells and in the white matter tracts (delineated by broken lines). See also Figure $7 C$. For abbreviations, see Appendix. Scale bars: $A, 0.75 \mathrm{~mm} ; B$ and $D, 180 \mu \mathrm{m} ; C, 90 \mu \mathrm{m} ; E, 140 \mu \mathrm{m}$.

Figure 3. Distribution of high-affinity kainate receptor mRNAs in coronal sections at level of subiculum (left column) and superior colliculi/pineal gland (right column). Arrows in $A$ mark the positions of small subthalamic nuclei that express the GluR-5 gene. The exact identity of these nuclei could not be confidently identified. See Appendix for abbreviations. Scale bar, $3.2 \mathrm{~mm}$. 
A

GiuR-5
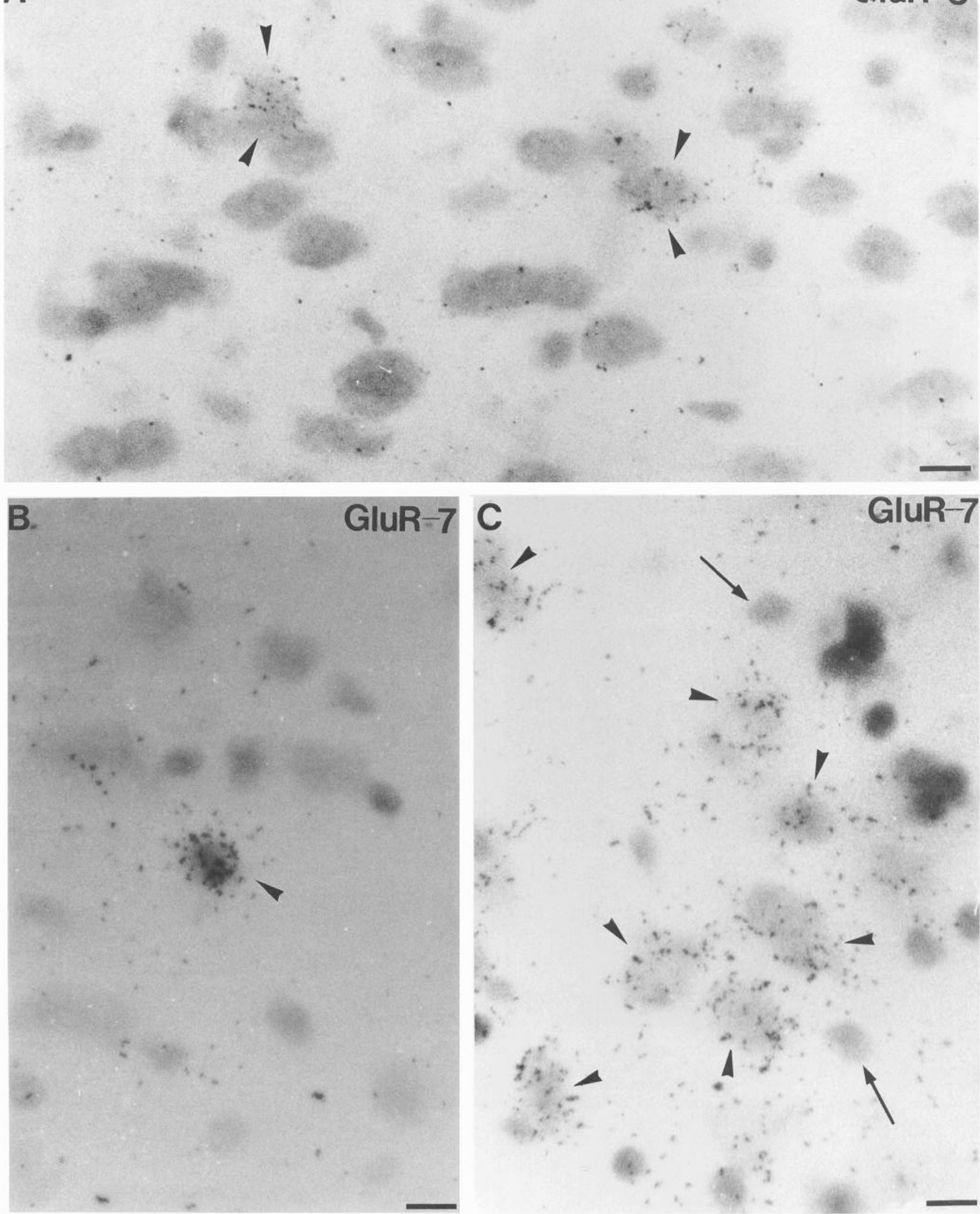

Figure 5. A, High-power bright-field photomicrograph illustrating occasional cells (arrowheads) in neocortex (layer IV) that contain GluR-5 mRNA. Most cells are unlabeled. $B$, An isolated layer II cell (arrowhead) of neocortex expressing the GluR-7 gene. See also Figure $4 B$. $C$, Many large, lightly staining cells (arrowheads) contain GluR-7 mRNA in layer VI of neocortex. Smaller stained cells (arrows), possibly corresponding to glia, have no accumulation of silver grains. Scale bars: $A$ and $B, 15 \mu \mathrm{m} ; C, 20 \mu \mathrm{m}$. 

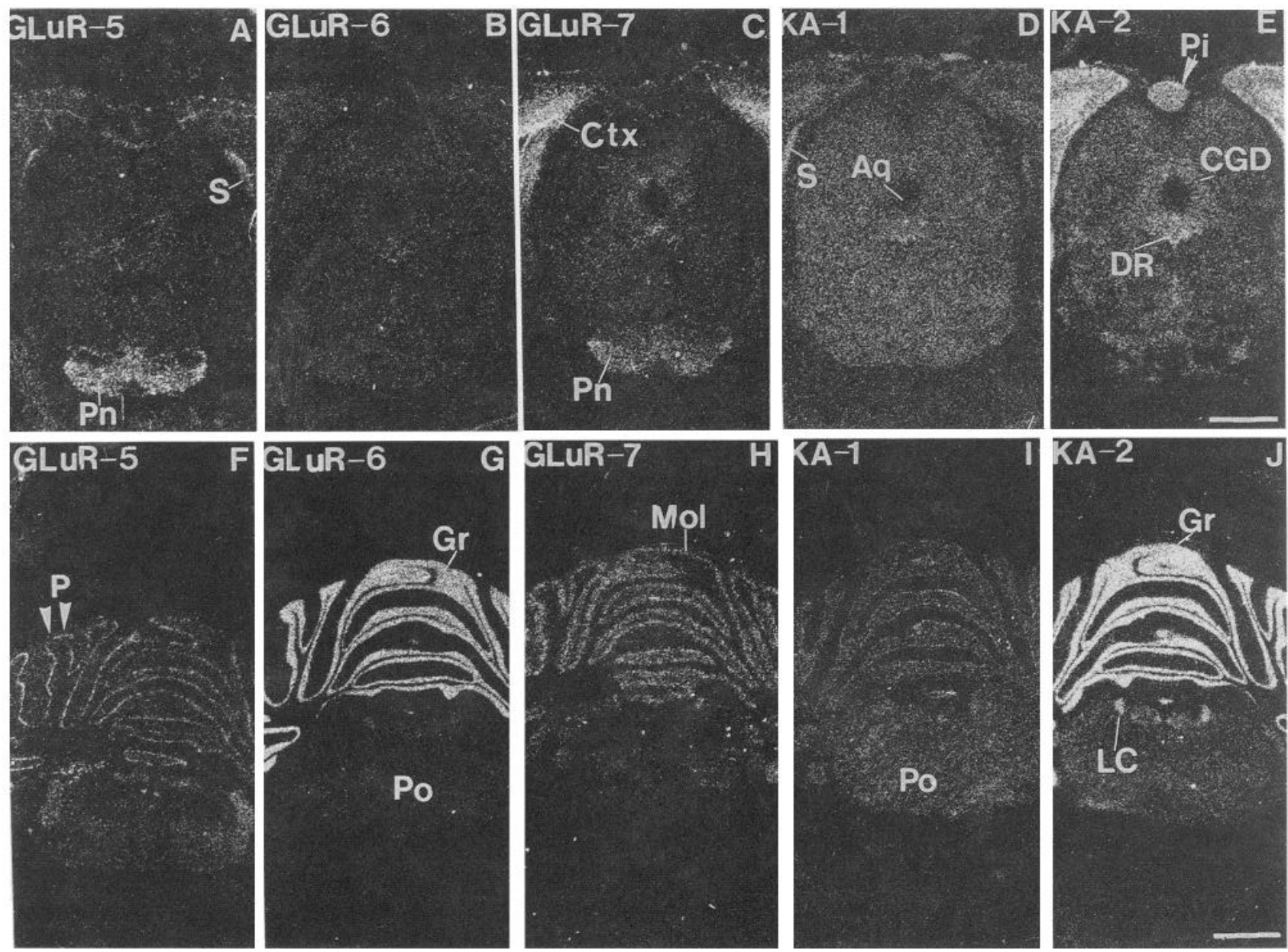

Figure 6. Distribution of high-affinity kainate receptor mRNAs in coronal sections at level of pontine nuclei/dorsal raphe (top row) and cerebellum (bottom row). See Appendix for abbreviations. Scale bars: $A-E, 1.8 \mathrm{~mm} ; F-J, 2.3 \mathrm{~mm}$.

medial nucleus (Fig. $2 J$ ), whereas the ventral medial hypothalamic nucleus contains solely GluR-7 at elevated levels (Fig. $2 F$ ). The medial preoptic and arcuate nuclei both express KA-2 and GluR-7 genes (Figs. $2 E, I ; 3 E, I)$. The suprachiasmatic nucleus has appreciable amounts of GluR-5 mRNA and KA-2 mRNA (Fig. 2A). The GluR-6 subunit mRNA is only present in low amounts in the hypothalamic nuclei examined here. As usual, the KA-1 probe gives a weak signal throughout the whole hypothalamic region (Figs. $2 G, H ; 3 G$ ).

\section{Colliculi}

In the superior colliculus, the GluR-5 gene is the only member to be expressed in a pronounced laminated manner (Fig. $3 B$ ). A significant line of GluR-5 expression is found in the intermediate gray layer (Fig. $3 B$ ). In contrast, the spatial expression of the other genes in the superior colliculus seems rather diffuse at the level of $\mathrm{x}$-ray film resolution (Fig. $3 D, F, H, J$ ), although all subunit genes are moderately expressed in this structure. In the regions of the inferior colliculus, all five subunit mRNAs are found at low but detectable levels (not shown).

\section{Brainstem/pons}

The pontine nuclei, situated within the basilar pons, are an important relay for cortical pathways to the cerebellum (Flumerfelt and Hrycyshyn, 1985). They contain notable levels of GluR-5 and GluR-7 mRNAs (Fig. 6A,C). The locus coeruleus, situated in the pontine tegmentum, is a major source of brain norepinephrine (reviewed in Loughlin and Fallon, 1985), and expresses the KA- 2 and (much more weakly) the GluR- 6 genes (Fig. $6 G, J$ ). The dorsal raphe, a major source of brain serotonin (Jacobs and Azmitia, 1992), contains KA-2 mRNA (Figs. 3J, $6 E$ ). The KA-1 signal is uniformly diffuse throughout the brainstem region.

There is not much evidence of rhombencephalic GluR-5 or GluR-6 expression. However, typical of the tendency for GluR-5 mRNAs to be abundant in brain regions whose electrophysiology and functions have been relatively little studied, the tegmental nuclei (probably either the rhabdoid or anterior tegmental nucleus; see Paxinos and Butcher, 1985; Paxinos and Watson, 1986) contain high levels of GluR-5 mRNA (Fig. 3B).

\section{Cerebellum}

As for other brain regions, the cell populations within the cerebellum express different combinations of kainate receptor subunits. The granule cells contain GluR-6 and KA-2 mRNAs (Fig. $6 G, J$ ). Cellular resolution for KA-2 and GluR-6 (data not shown) reveals that Purkinje cells are not labeled with these probes above general grain background. At the level of $x$-ray film analysis, both KA-1 and GluR-5 are present in the Purkinje cell layer (Fig. $6 F, I$ ). Cellular resolution confirms that Purkinje cells (but not Bergmann glia) express GluR-5 and KA-1 transcripts (Figs. $4 D, E ; 7 A$ ). Putative stellate/basket cells in the molecular 


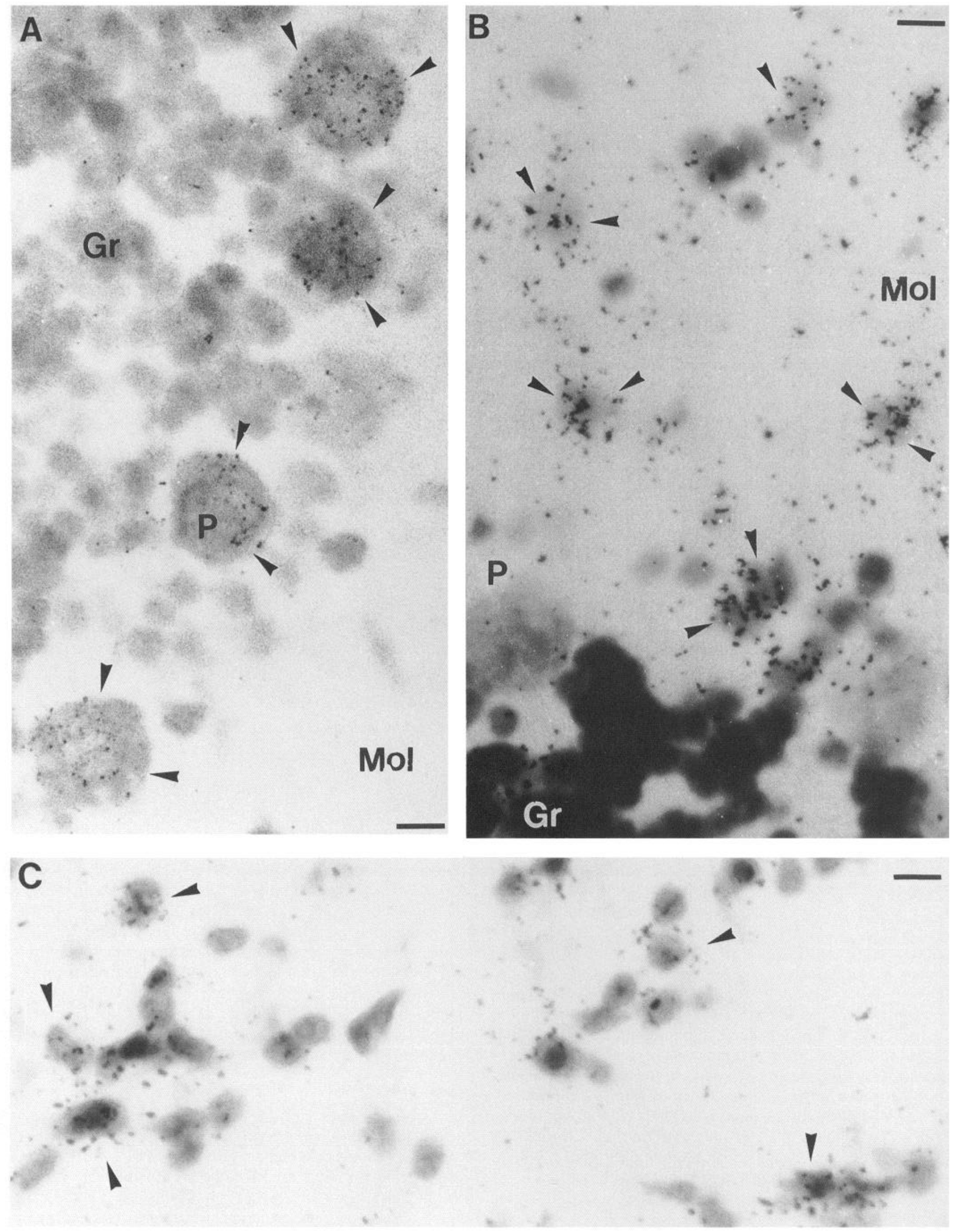

Figure 7. A, High-power bright-field photomicrograph illustrating cerebellar Purkinje cells (arrowheads) expressing the GluR-5 gene. See also Figure 4D. B, GluR-7 mRNA is found in putative stellate/basket cells (arrowheads) in the molecular layer of cerebellum. Purkinje cells are unlabeled. $C, \mathrm{KA}-1$ expression in cerebellar white matter tracts. Numerous small stained cells (arrowheads) exhibit clusters of silver grains over them suggesting that they weakly express the KA-1 gene. See also Figure $4 E$. See appendix for abbreviations. Scale bars: $A$ and $B, 18 \mu \mathrm{m} ; C, 15 \mu \mathrm{m}$. 
layer express the GluR-7 gene (Fig. $7 B$ ), but none of the other subunit mRNAs are noticeably present in this layer.

\section{White matter tracts}

A surprising result is a weak but specific signal obtained with KA-1 probes in white matter. The signal is most noticeable in the corpus callosum (Fig. $8 B$ ), in the anterior commissure (Fig. $1 \mathrm{H}$ ), and in the white matter tracts of the cerebellum (Fig. $7 \mathrm{C}$ ). In the forebrain, the KA-1 cortical layer VI signal is continuous with the corpus callosum labeling. This is shown in Figure $8 B$. For GluR-7 and KA-2, the signal in the subiculum and cortex is clearly elevated relative to that of the corpus callosum (Fig. $8 A, C)$. However, for $\mathrm{KA}-1$, the autoradiographic signal is such that the corpus callosum is "filled in" between cortex and subiculum (Fig. $8 B$ ). This signal is specific by all criteria, including the use of three different oligonucleotides (see Materials and Methods) hybridizing to different regions of the KA-1 mRNA. Further confirmation of specificity is provided by the demonstration that silver grains are lightly but discretely clustered over cell bodies (presumably glia) in the cerebellar white matter tracts (Fig. 7C). The diffuse autoradiographic signal (with the exception of the CA3 pyramidal cells) seen with KA-1 probes on all brain regions may be indicative of a general glial cell labeling.

\section{Pineal gland}

KA-2 mRNA is the only high-affinity kainate receptor subunit transcript detectable in the pineal gland (Figs. $3 J, 6 E$ ).

\section{Discussion}

We performed a systematic comparison of the distribution in the adult rat brain of mRNAs encoding the five high-affinity kainate receptor subunits, KA-1, KA-2, and GluR-5-GluR-7. The KA-1 mRNA occurs mainly in the CA3 field of the hippocampus and in dentate gyrus, with much lower amounts being found in inner cortical layers, cerebellar Purkinje cells, and white matter; the KA-2 gene is almost near universally expressed, with its mRNA being detected in many neuronal nuclei; GluR-5 transcripts are found in cingulate and piriform cortex, the subiculum, various septal nuclei, and Purkinje cells; GluR-6 mRNA is most abundant in cerebellar granule cells, with lower levels in caudate-putamen and hippocampus; the GluR-7 gene is prominently expressed in the inner cortical layers, cingulate cortex, subiculum, caudate-putamen, reticular thalamus, and putative stellate/basket cells in the cerebellum. We conclude that there is likely to exist a rich mosaic of functionally distinct high-affinity kainate receptors in the vertebrate brain.

The highest amounts of high-affinity ${ }^{3} \mathrm{H}$-kainate binding are found in layer I and the inner laminae of the neocortex and cingulate cortex, the superficial layers of the piriform cortex, caudate-putamen, CA3 sector of the hippocampus, reticular thalamic nucleus, hypothalamic median eminence, and the granule cell layer of the cerebellum (Foster et al., 1981; Monaghan and Cotman, 1982; Unnerstall and Wamsley, 1983; Miller et al., 1990). As for all mRNA mapping studies, there is no direct evidence that the amounts of kainate subunit mRNA actually reflect protein levels, but the combined expression patterns of the five subunit genes approximate to the autoradiographic pattern observed for high-affinity ${ }^{3} \mathrm{H}$-kainate sites in the rat brain. For example, four subunit genes are expressed in the dentate granule cells (KA-1, KA-2, GluR-6, GluR-7), which has a density of high-affinity kainate sites of roughly $170 \mathrm{fmol} / \mathrm{mg}$ protein (Monaghan et al., 1986; Miller et al., 1990). In contrast,
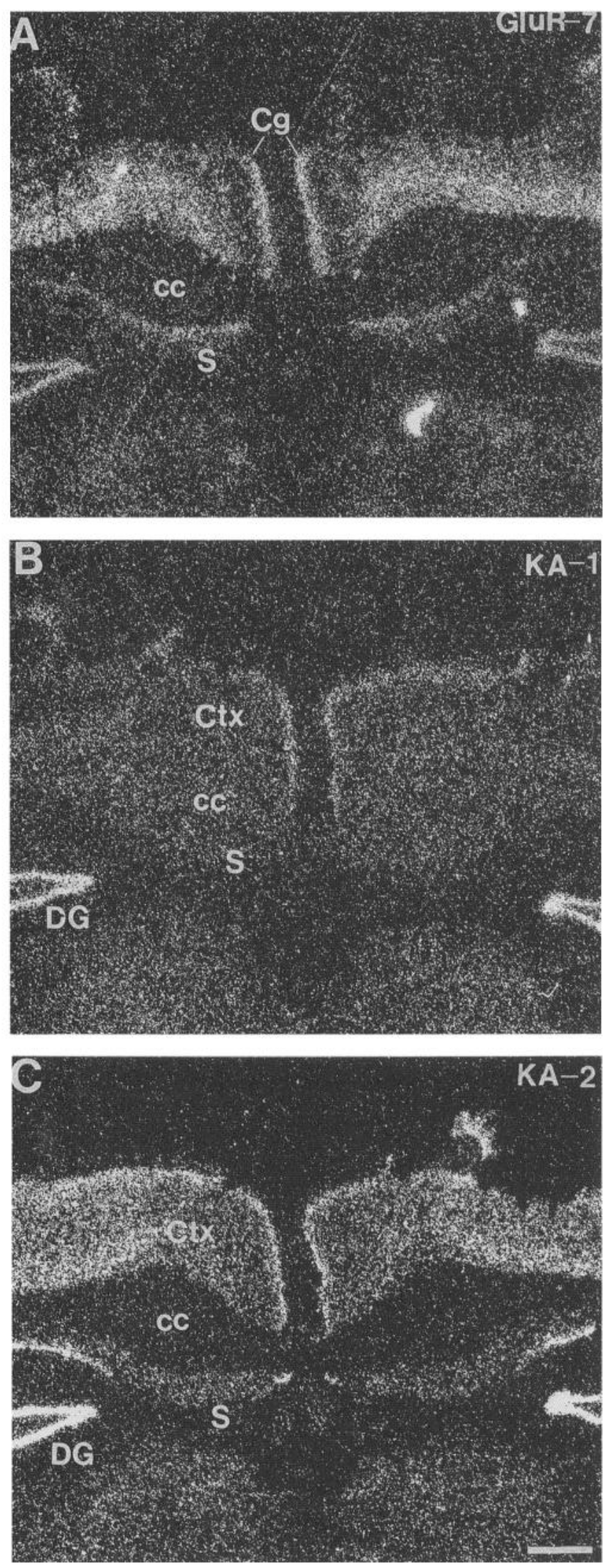

Figure 8. X-ray film autoradiographs illustrating KA-1 gene expression $(B)$ in the corpus callosum. The expression of the KA-1 gene is continuous between deep cortical layers and the corpus callosum. In contrast, GluR-7 $(A)$ and KA-2 $(C)$ probes do not label the corpus callosum. See Appendix for abbreviations. Scale bar, $1.5 \mathrm{~mm}$. 
the CAl sector has a high-affinity kainate site density of only $90 \mathrm{fmol} / \mathrm{mg}$ protein, that is, roughly half that found in the dentate region (Monaghan et al., 1986; Miller et al., 1990), which perhaps corresponds with only two subunit genes (KA-2 and GluR-6) being expressed in this sector.

Nevertheless, as discussed by Monaghan and Anderson (1991), autoradiographic studies may detect only subpopulations of receptors. This may be because ligand binding studies of the average receptor population on membranes derived from whole brain have generally been used to define the conditions for autoradiography. Alternatively, areas that have low levels of binding may have some form of "masked" receptor. Mismatches between binding and mRNA distributions are common observations for other ligand-gated ion channels. For example, for the $\mathrm{G} \wedge \mathrm{B} \Lambda_{\mathrm{A}}$ receptor system, the anatomical presence of certain $\alpha$-subunit mRNAs is not reflected by the detection of corresponding binding sites (Olsen et al., 1990; Persohn et al., 1991; Wisden et al., 1992).

\section{Expression mosaics of kainate receptor subunits}

As outlined in the introductory remarks, one hypothesis suggested by in vitro expression of recombinant subunits is that members of the KA and GluR-5-GluR-7 subunit classes form heteromeric assemblies in vivo. Thus, potentially two types of non-NMDA EAA receptor channels might be found in vivo: the traditional high-affinity AMPA/low-affinity kainate receptor and a novel low-affinity AMPA/high-affinity kainate type (Herb et al., 1992; Sakimura et al., 1992). However, homomeric configurations, especially those of GluR-5 and GluR-6 subunits, might also be found. The issue is complicated by the existence of the two high-affinity kainate sites with $K_{D}$ values of 5 and $50 \mathrm{~nm}$, respectively (London and Coyle, 1979; Hampson et al., 1987). It has been claimed that these two sites are differentially sensitive to the presence of calcium in the binding medium, that they are differentially distributed, and that they display differential responses to denervation and reinnervation within the rat hippocampus (Honoré et al., 1986; Monaghan et al., 1986; reviewed by Monaghan and Anderson, 1991). Although the KA and GluR-5-GluR-7 subunit classes seem to reflect these two sites, the exact relationship is not clear. For example, recombinant heteromeric KA/GluR channels have an affinity for kainate averaging $50-100 \mathrm{~nm}$. The $5 \mathrm{~nm}$ site is only generated by homomeric KA assemblies that fail to form channels when expressed on the surface of fibroblast cell lines or Xenopus oocytes (Werner et al., 1991; Herb et al., 1992; Sakimura et al., 1992), but it is uncertain whether the $5 \mathrm{~nm}$ site on brain membranes is solely due to nonfunctional KA homomerics.

Therefore, in the absence of critical testing by immunoprecipitation, it is of interest to examine possible partnership relations among high-affinity kainate receptor subunits. Examples of regional mRNA colocalizations are legion: for example, KA-2 and GluR-7 subunit mRNAs prominently colocalize in deep cortical layers; the dentate granule cells of hippocampus express GluR-6, GluR-7, KA-1, and KA-2; the GluR-6, KA-1, and KA-2 mRNAs are in the CA3 pyramidal cells of hippocampus, with GluR-6 and KA-2 transcripts in CA1 pyramidal cells; GluR5, GluR-6, and KA-2 are particularly prominent in the piriform cortex; the suprachiasmatic nucleus contains GluR-5 and KA-2 transcripts; cerebellar granule cells contain GluR-6 and KA-2; Purkinje cells contain GluR-5 and KA-1 mRNAs; certain layers of the subiculum and the pontine nuclei contain mainly GluR-5 and GluR-7. Some areas (e.g., layer II, cingulate cortex) express all five subunit mRNAs.

Examples of mismatches are equally numerous. Noteworthy examples include the reticular thalamic nucleus and the molecular layer of the cerebellum (only GluR-7 mRNA), the pineal gland (only KA-2 mRNA), the dorsal medial (largely KA-2 mRNA) and ventral medial (largely GluR-7) hypothalamic nuclei, and the sole (or at least huge excess) presence of GluR-5 transcripts in certain septal, thalamic, superior collicular, and tegmental nuclei. Such mismatches may suggest the existence of further unknown members of the gene family, or of homomeric receptors in these regions. Considering the case of the reticular thalamic nucleus, this region may express predominantly homomeric configurations, although much lesser amounts of GluR-6, KA-1, and KA-2 mRNA are also present in this nucleus. Other non-NMDA ionotropic receptor subunits are found in the reticular thalamus, in particular GluR-D (Bettler et al., 1990; Keinänen et al., 1990; Petralia and Wenthold, 1992), but coexpression in vitro of GluR-D and GluR-7 fails to produce any emergent properties (Lomeli et al., 1992; H. Lomeli and P. $H$. Seeburg, unpublished observations). Similarly, in the cerebellar stellate/basket cells, GluR-7 and GluR-C may be coexpressed (Keinänen et al., 1990; Petralia and Wenthold, 1992). Another obvious mismatch in mRNA abundance is found in the neocortex. Here, KA-2 mRNA is abundant in the outer cortical laminae (layer II) and seems to be found in most neurons (Fig. 4B). No other high-affinity kainate receptor subunit gene is expressed at comparable levels in this area, with GluR-7 transcripts being abundant in only occasional layer II cells (Figs. $4 C, 5 B)$.

As a further complication, three GluR-5 C-terminal splice variants exist (Sommer et al., 1992) and each of these three forms can carry additional functional amino acid changes conferred by RNA editing, resulting in potential changes in channel permeability to Ca2 + (Sommer et al., 1991; Köhler et al., 1993). It may prove impossible using antibody or in situ hybridization approaches to distinguish between the different edited GluR-5 and GluR-6 forms. Thus, a complete knowledge of exactly which GluR-5 and GluR-6 subunit type and associated partners [e.g., KA-2/GluR-6(Q) or KA-2/GluR-6(R)] are present in any given cell may remain elusive. Single-cell PCR methods might prove useful for this problem (Lambolez et al., 1992; Mackler et al., 1992).

\section{Cellular location of high-affinity kainate receptors}

Recombinantly expressed receptor channels of high-affinity kainate subunits rapidly desensitize in the presence of kainate (Egebjerg et al., 1991; Sommer et al., 1992; Herb et al., 1992), a situation quite different from the nondesensitizing current responses observed for kainate application to AMPA/low-affinity kainate-gated channels (Boulter et al., 1990; Keinänen et al., 1990). Unfortunately, the concept of such rapidly desensitizing kainate-gated channels corresponding to the high-affinity binding sites in the CNS has been severely compromised by an inability to detect them by electrophysiological measurements (P. Jonas and B. Sakmann, personal communication). Only in the PNS (dorsal root ganglia) has an apparently pure population of rapidly desensitizing kainate receptors, possibly corresponding to GluR-5 homomerics (see below) been detected (Heuttner, 1990; Sommer et al., 1992). In contrast, in the CNS, definitive functional evidence for a high-affinity site has been lacking. Most electrophysiological studies of kainate in the brain have 
produced results consistent with activation of the AMPA/lowaffinity kainate-gated channels (reviewed by Henley et al., 1989; Keinänen et al., 1990; Patneau and Mayer, 1991; Jonas and Sakmann, 1992, and references therein). A few studies have demonstrated that application of low (nanomolar) concentrations of kainate onto the dendritic fields of CA3 pyramidal cells caused subtle changes in neuronal excitability in a neuromodulatory fashion (Robinson and Deadwyler, 1981; Westbrook and Lothman, 1983) but did not claim any direct depolarizing effects.

Failure to detect fast desensitizing kainate responses could be because of masking by the possibly more abundant AMPA/lowaffinity kainate-gated channels. On the other hand, functional high-affinity kainate receptors might reside exclusively on dendrites and/or presynaptic terminals, thus eluding detection by conventional patch-clamp methods.

One idea is that high-affinity kainate receptors would function as presynaptic "autoreceptors." Consistent with this notion, in vivo kainate-mediated excitotoxic lesions of, for example, striatal neurons or hippocampal dentate granule cells are often only effective if the excitatory efferent inputs to these cell populations arc intact (revicwed by Coylc, 1983). For cxample, if kainatc is injected into the normally innervated rat caudate-putamen, it destroys most of the neurons in this structure. However, if the glutamatergic cortical inputs to the striatum are removed by decortication, caudate-putamen neurons become more resistant to kainate-mediated death. Thus, kainate could be promoting glutamate release from the cortical terminals, possibly via KA/ GluR-5-GluR-7 autoreceptors, and this endogenously released glutamate kills the cells (Ferkany et al., 1982; Coyle, 1983; Poli et al., 1985). This interpretation has been vigorously contested and the issue remains controversial (Garthwaite and Garthwaite, 1983; Pocock et al., 1988). Other evidence to suggest at least a partial presynaptic localization for high-affinity kainate receptors comes from lesioning studies of the hippocampal dentate granule cells (Repressa et al., 1987; although see Monaghan and Cotman, 1982). In this system, killing of the granule cells leads to degencration of thcir axons, the mossy fibcrs, which synapse onto the dendritic trees of the CA3 pyramidal neurons. The majority of the CA3 high-affinity kainate binding also disappears, one interpretation of which is that the binding site resides presynaptically on the mossy fiber terminals (Repressa et al., 1987). Consistent with this, a $100 \%$ increase in ${ }^{3} \mathrm{H}$-kainic acid binding in the CA 3 region is observed between 7 and 21 $\mathrm{d}$ after birth, coinciding with the postnatal development of the mossy fiber projection (Miller et al., 1990). However, there may be at least some postsynaptic high-affinity kainate receptor component on the mossy fiber-CA3 synapse because of the high levels of KA-1 mRNA in CA3 pyramidal cells.

A strong argument for a dendritic localization is that highaffinity kainate binding in layer I of neocortex is very high (Monaghan and Cotman, 1982; Unnerstall and Wamsley, 1983), but this layer contains very few cell soma. Hence, the binding may originate on dendrites of layer II or deeper cells expressing the KA-2 subunit (see Fig. $4 B$ ). Similarly, the presence of highaffinity kainate sites in the denervated dentate gyrus molecular layer (e.g., Ulas et al., 1990) also argues for a dendritic location. Some high-affinity kainate receptors may be altogether extrasynaptic as found in the frog CNS using immunocytochemistry (Dechesne et al., 1990). Very recently, preliminary direct support for a dendritic location of the GluR-5-GluR-7 subunits in primate cortex and hippocampus has been made using subunit- specific monoclonal antibodies (Good et al., 1992; Morrison et al., 1992). For example, in the case of hippocampal dentate granule cells, immunoreactivity for these subunits is claimed to be confined exclusively to the cell dendrites, with the soma showing no immunoreactivity (Good et al., 1992).

\section{Some possible functional roles of high-affinity kainate-gated channels}

Despite the current technical difficulties in detecting high-affinity kainate-gated channels, such receptors are likely to be widespread and involved in the function of all neuronal circuits based on both previous ligand binding data (Monaghan and Cotman, 1982; Unnerstall and Wamsley, 1983; Miller et al., 1990) and the in situ hybridization observations. We highlight a few of these possible involvements below.

A direct involvement of NMDA and AMPA/low-affinity kainate receptors in transmission of photic stimulation in the hypothalamic suprachiasmatic nucleus has recently been documented (Colwell et al., 1990; Takeuchi et al., 1991). The expression of KA-2/GluR-5 genes in the suprachiasmatic nucleus and KA-2 in the pineal gland, our previous observation that the KA-2 gene is expressed in embryonic pituitary (Herb et al., 1992), and the detection of high-affinity binding sites in the adult pituitary (Unnerstall and Wamsley, 1983) all highlight the potential role of high-affinity kainate receptors in the regulation of neuroendocrine and circadian functions. There is some evidence to suggest that glutamate, possibly released onto the pineal from the central pinealopetal fibers, inhibits melatonin production (see Krause and Dubocovich, 1990, and references therein).

Considering other regions of the hypothalamus, the studies of van den Pol et al. (1990) have emphasized the general contribution of glutaminergic transmission to neuroendocrine regulation. The abundance of various receptor transcripts in the hypothalamus (e.g., GluR-7 in the ventral medial nucleus, KA-2 in dorsal medial, arcuate, and medial preoptic nuclei) supports this notion. The potential assembly of KA-2-containing receptors on dorsal raphe neurons (a major source of brain 5-HT; Jacobs and Azmitia, 1992) and on the locus cocrulcus (a major source of noradrenergic fibers projecting throughout the brain; Loughlin and Fallon, 1985) implies high-affinity kainate receptors may also regulate these important modulatory neurotransmitter systems.

The detection of KA-1 mRNA in white matter tracts (corpus callosum, anterior commissure, and white matter tracts in cerebellum), and possibly glial elements in the gray matter, would be consistent with a large body of evidence suggesting the presence of non-NMDA receptors on glial cells (e.g., Sontheimer et al., 1988; Usowicz et al., 1989; Cornell-Bell et al., 1990; Jensen and Chiu, 1990; Somogyi et al., 1990; Burnashev et al., 1992; Müller et al., 1992). Interestingly, low but detectable amounts of displaceable high-affinity kainate binding have been reported to be present in the rat corpus callosum, with the binding showing a developmental peak in expression at 2 weeks after birth (Miller et al., 1990). Although the exact function of glial nonNMDA receptors is not appreciated, their activation seems to be a widespread occurrence throughout the CNS, often leading to sustained calcium oscillations (reviewed by Barres, 1991).

\section{Conclusions}

In this article we have emphasized the extreme complexity of the high-affinity kainate receptor system in the rat brain, basing our conclusions on the intricate autoradiographic patterns pro- 
duced by in situ hybridization. High-affinity kainate receptors, presumably activated in vivo by glutamate, are obviously likely to be very widespread and active in most neuronal circuits. If one assumcs a heteromcric model of asscmbly for these receptors (i.e., KA-1, KA-2/GluR-5-GluR-7 subunit pairings), then the large number of noted regional mismatches in mRNA abundance could suggest missing subunit partners. Alternatively, receptor configurations assembled from just one subunit type may be found in some brain nuclei. Immunocytochemistry with subunit-specific antibodies will provide the next step forward in understanding these receptors.

\section{Appendix}

$\begin{array}{ll}\text { ac } & \text { Anterior commissure } \\ \text { AO } & \text { Anterior olfactory nucleus } \\ \text { Arc } & \text { Arcuate hypothalamic nucleus } \\ \text { Aq } & \text { Aqueduct } \\ \text { AV } & \text { Anteroventral thalamic nucleus } \\ \text { BST } & \text { Bed nucleus stria terminalis } \\ \text { cc/CC } & \text { Corpus callosum } \\ \text { Cg } & \text { Cingulate cortex } \\ \text { CGD } & \text { Central gray, dorsal } \\ \text { CPu } & \text { Caudate-putamen } \\ \text { Ctx } & \text { Neocortex } \\ \text { DG } & \text { Dentate granule cells } \\ \text { DM } & \text { Dorsomedial hypothalamic nucleus } \\ \text { DR } & \text { Dorsal raphc } \\ \text { Fr } & \text { Frontal neocortex } \\ \text { GP } & \text { Globus pallidus } \\ \text { Gr } & \text { Cerebellar granule cells } \\ \text { HDB } & \text { Nucleus horizontal limb diagonal band } \\ \text { LC } & \text { Locus coeruleus } \\ \text { LSI } & \text { Lateral septal nucleus, intermediate } \\ \text { MHb } & \text { Medial habenular nucleus } \\ \text { Mol } & \text { Molecular layer of cerebellum } \\ \text { MPA } & \text { Medial preoptic area } \\ \text { MS } & \text { Medial septal nucleus } \\ \text { P } & \text { Purkinje cell/Purkinje cell layer } \\ \text { Pi } & \text { Pineal gland } \\ \text { Pir } & \text { Piriform cortex } \\ \text { Pn } & \text { Pontine nuclei } \\ \text { Po } & \text { Pons } \\ \text { Rbd } & \text { Rhabdoid nucleus } \\ \text { Rt } & \text { Reticular thalamic nucleus } \\ \text { S } & \text { Subiculum } \\ \text { SC } & \text { Superior colliculus } \\ \text { SCh } & \text { Suprachiasmatic nucleus } \\ \text { VI } & \text { Layer 6 of neocortex } \\ \text { VM } & \text { Ventromedial hypothalamic nucleus } \\ \text { WM } & \text { White matter } \\ & \end{array}$

\section{References}

Agrawal SG, Evans RH (1986) The primary afferent depolarizing action of kainate in the rat. Br J Pharmacol 87:345-355.

Barres BA (1991) Glial ion channels. Curr Opin Neurobiol 1:354359.

Bettler B, Boulter J, Hermans-Borgmeyer I, O'Shea-Greenfield A, Deneris ES, Moll C, Borgmeyer U, Hollmann M, Heinemann S (1990) Cloning of a novel glutamate receptor subunit, GluR-5: expression in the nervous system during development. Neuron 5:583-595.

Bettler B, Egebjerg J, Sharma G, Pecht G, Hermans-Borgmeyer I, Moll C, Stevens CF, Heinemann S (1992) Cloning of a putative glutamate receptor: a low affinity kainate-binding subunit. Neuron 8:257-265.

Blackstonc CD, Moss SJ, Martin LJ, Levey AI, Price DL, Huganir RL (1992) Biochemical characterization and localization of a non- $N$ methyl-D-aspartate glutamate receptor in rat brain. J Neurochem 58: $1118-1126$

Boulter J, Hollmann M, O'Shea-Greenfield A, Hartley M, Deneris E, Maron C, Heinemann S (1990) Molecular cloning and functional expression of glutamate receptor subunit genes. Science 249:10331037.
Burnashev N, Khodorova A, Jonas P, Helm PJ, Wisden W, Monyer H, Sccburg PH, Sakmann B (1992) Calcium-permcable AMPAkainate receptors in fusiform cerebellar glial cells. Science 256:15661570.

Colwell CS, Ralph MR, Menaker M (1990) Do NMDA receptors mediate the effects of light on circadian behavior? Brain Res 523: $117-120$

Cornell-Bell AH, Finkbeiner SM, Cooper MS, Smith SJ (1990) Glutamate induces calcium waves in cultured astrocytes: long range glial signalling. Science 247:470-473.

Coyle JT (1983) Neurotoxic action of kainic acid. J Neurochem 41: $1-11$.

Dechesne CJ, Oberdorfer MD, Hampson DR, Wheaton KD, Nazarali AJ, Goping G, Wenthold RJ (1990) Distribution of a putative kainic acid receptor in the frog central nervous system determined with monoclonal and polyclonal antibodies: cvidence for synaptic and extrasynaptic localization. J Neurosci 10:479-490.

Egebjerg J, Bettler B, Hermans-Borgmeyer I, Heinemann S (1991) Cloning of a cDNA for a glutamate receptor subunit activated by kainate but not by AMPA. Nature 351:745-748.

Ferkany JW, Zaczek R, Coyle JT (1982) Kainic acid stimulates excitatory amino acid neurotransmitter release at presynaptic receptors. Nature 298:757-759.

Flumerfelt BA, Hrycyshyn AW (1985) Precerebellar nuclei and red nucleus. In: The rat nervous system, Vol 2, Hindbrain and spinal cord (Paxinos G, ed), pp 221-250. New York: Academic.

Foster AC, Mena EE, Monaghan DT, Cotman CW (1981) Synaptic localization of kainic acid binding sites. Nature 289:73-75.

Garthwaite J, Garthwaite $G$ (1983) The mechanism of kainic acid neurotoxicity. Nature 305:138-140.

Gasic GP, Hollmann M (1992) Molecular neurobiology of glutamate receptors. Annu Rev Physiol 54:507-536.

Good PF, Moran T, Rogers SW, Heinemann S, Morrison JH (1992) Distribution of the kainate class glutamate receptor subunits (GluR5-GluR-7) in the temporal cortex of the macaque: localization to identified projection neurons of the entorhinal cortex. Soc Neurosci Abstr 18:1466.

Gregor P, Mano I, Maoz I, McKeown M, Teichberg VI (1989) Molecular structure of the chick cerebellar kainate-binding subunit of a putative glutamate receptor. Nature 342:689-692.

Hampson DR, Huie D, Wenthold RJ (1987) Solubilization of kainic acid binding sites from rat brain. J Neurochem 49:1209-1215.

Henley JM, Barnard EA (1991) Comparison of solubilized kainate and $\alpha$-amino-3-hydroxy-5-methylisoxazolepropionate binding sites in chick cerebellum. J Neurochem 56:702-705.

Henley JM, Ambrosini A, Krogsgaard-Larsen P, Barnard EA (1989) Evidence for a single glutamate receptor of the ionotropic kainate/ quisqualate type. New Biol 1:153-158.

Herb A, Burnashev N, Werner P, Sakmann B, Wisden W, Seeburg PH (1992) The KA-2 subunit of excitatory amino acid receptors shows widespread expression in brain and forms ion channels with distantly related subunits. Neuron 8:775-785.

Hollmann M, O'Shea-Greenfield A, Rogers SW, Heinemann S (1989) Cloning by functional expression of a member of the glutamate receptor family. Nature 342:643-648.

Honoré T, Drejer J, Nielsen M (1986) Calcium discriminates two $\left[{ }^{3} \mathrm{H}\right] \mathrm{kainate}$ binding sites with different molecular target sizes in rat cortex. Neurosci Lett 65:47-52.

Huettner JE (1990) Glutamate receptor channels in rat DRG neurons: activation by kainate and quisqualate and blockade of desensitization by Con A. Neuron 5:255-266.

Jacobs BL, Azmitia EC (1992) Structure and function of the brain serotonin system. Physiol Rev 72:165-229.

Jensen AM, Chiu S (1990) Fluorescence measurement of changes in intracellular calcium induced by excitatory amino acids in cultured cortical astrocytes. J Neurosci 10:1165-1175.

Jonas P, Sakmann B (1992) Glutamate receptor channels in isolated patches from $\mathrm{CA} 1$ and $\mathrm{CA} 3$ pyramidal cells of rat hippocampal slices. J Physiol (Lond) 455:143-171.

Keinänen K, Wisden W, Sommer B, Werner P, Herb A, Verdoorn TA, Sakmann B, Seeburg PH (1990) A family of AMPA-selective glulamate receptors. Science 249:556-560.

Köhler M, Burnashev N, Sakmann B, Seeburg PH (1993) Determinants of $\mathrm{Ca}^{2+}$ permeability in both TM1 and TM2 of high-affinity kainate receptor channels: diversity by RNA editing. Neuron 10:in press. 
Krause DN, Dubocovich ML (1990) Regulatory sites in the melatonin system of mammals. Trends Neurosci 13:464-470.

Lambolez B, Audinat E, Bochet P, Crepel F, Rossier J (1992) AMPA receptor subunits expressed by single cells. Neuron 9:247-258.

Lomeli H, Wisden W, Köhler M, Keinänen K, Sommer B, Seeburg PH (1992) High-affinity kainate and domoate receptors in rat brain. FEBS Lett 307:139-143.

Lomeli H, Sprengel R, Laurie DJ, Köhr G, Herb A, Seeburg PH, Wisden W (1993) The rat delta-1 and delta-2 subunits extend the excitatory amino acid receptor family. FEBS Lett $315 \cdot 318-322$.

London ED, Coyle JT (1979) Specific binding of [ $\left.{ }^{3} \mathrm{H}\right]$ kainic acid to receptor sites in the rat brain. Mol Pharmacol 15:492-505.

Loughlin SE, Fallon JH (1985) Locus coeruleus. In: The rat nervous system, Vol 2, Hindbrain and spinal cord (Paxinos G, ed), pp 79-93. New York: Academic.

Mackler SA, Brooks BP, Ebcrwine JH (1992) Stimulus-induccd coordinate changes in mRNA abundance in single postsynaptic hippocampal CA1 neurons. Neuron 9:539-548.

Martin LJ, Blackstone CD, Huganir RL, Price DL (1992) Cellular localization of a metabotropic glutamate receptor in rat brain. Neuron 9:259-270.

Miller LP, Johnson AE, Gelhard RE, Insel TR (1990) The ontogeny of excitatory amino acid receptors in the rat forebrain. II. Kainic acid receptors. Neuroscience 35:45-51.

Monaghan DT, Anderson KJ (1991) Heterogeneity and organization of excitatory amino acid receptors and transporters. In: Excitatory amino acids and synaptic function (Wheal $\mathrm{H}$, Thomson $\mathrm{A}$, eds), pp 33-54. New York: Academic.

Monaghan DT, Cotman CW (1982) The distribution of $\left[{ }^{3} \mathrm{H}\right] \mathrm{kainic}$ acid binding sites in rat CNS as determined by autoradiography. Brain Res 252:91-100.

Monaghan DT, Nguyen L, Cotman CW (1986) The distribution of $\left[{ }^{3} \mathrm{H}\right]$ kainate binding sites in primate hippocampus is similar to the distribution of both $\mathrm{Ca}^{2+}$-sensitive and $\mathrm{Ca}^{2+}$-insensitive $\left[{ }^{3} \mathrm{H}\right] \mathrm{kainate}$ binding sites in rat hippocampus. Neurochem Res 11:1073-1082.

Monaghan DT, Bridges RJ, Cotman CW (1989) The excitatory amino acid receptors: their classes pharmacology and distinct properties in the function of the central nervous system. Annu Rev Pharmacol Toxicol 29:365-402

Morrison JH, Vickers JC, Huntley GW, Good PF, Janssen WG, Archin N, Moran T, Rogers SW, Heinemann SF (1992) Distribution of glutamate receptor subunit proteins in monkey neocortex. Soc Neurosci Abstr 18:1467.

Müller T, Möller T, Berger T, Schnitzer J, Kettenmann H (1992) Calcium entry through kainate receptors and resulting potassium-channel blockade in Bergmann glial cells. Science 256:1563-1566.

Nadler JV, Perry BW, Cotman CW (1978) Intraventricular kainic acid preferentially destroys hippocampal pyramidal cells. Nature 271:676677.

Nakanishi N, Schneider NA, Axel R (1990) A family of glutamate receptor genes: evidence for the formation of heteromultimeric receptors with distinct channel properties. Neuron 5:569-581.

Olsen RW, McCabe RT, Wamsley JK (1990) GABA A receptor subtypes: autoradiographic comparison of GABA, benzodiazepine and convulsant binding sites in the rat central nervous system. J Chem Neuroanat 3:59-76.

Patneau DK, Mayer ML (1991) Kinetic analysis of interactions between kainate and AMPA: evidence for the activation of a single receptor in mouse hippocampal neurons. Neuron 6:785-798.

Paxinos G, Butcher LL (1985) Organizational principles of the brain as revealed by choline acetyltransferase and acetylcholinesterase distribution and projections. In: The rat nervous system, Vol 1, Forebrain and midbrain (Paxinos G, ed), pp 487-522. New York: Academic.

Paxinos G, Watson C (1986) The rat brain in stereotaxic coordinates 2d ed. Sydney: Academic.

Persohn E, Malherbe P, Richards JG (1991) In situ hybridization histochemistry reveals a diversity of $\mathrm{GABA}_{\mathrm{A}}$ receptor subunit mRNAs in neurons of the rat spinal cord and dorsal root ganglia. Neuroscience 42:497-507.

Petralia RS, Wenthold RJ (1992) Light and electron immunocytochemical localization of AMPA-selective glutamate receptors in the rat brain. J Comp Neurol 318:329-354.

Pocock JM, Murphie HM, Nicholls DG (1988) Kainic acid inhibits the synaptosomal plasma membrane glutamate carrier and allows glutamate leakage from cytoplasm but does not affect glutamate exocytosis. J Neurochem 50:745-751.

Poli A, Contestabile A, Migani P, Rossi L, Rondelli C, Virgili M, Bissoli $R$, Barnabei $O$ (1985) Kainic acid differentially affects the synaptosorilal release of endogenous and exogenous amino acid neurotransmitters. J Neurochem 45:1677-1686.

Pruss RM, Akeson RL, Racke MM, Wilburn JL (1991) Agonist-activated cobalt uptake identifies divalent cation-permeable kainate receptors on neurons and glial cells. Neuron 7:509-518.

Repressa A, Tremblay E, Ben-Ari Y (1987) Kainate binding sites in the hippocampal mossy fibers: localization and plasticity. Neuroscience 20:739-748.

Robinson JH, Deadwyler SA (1981) Kainic acid promotes depolarization of CA 3 pyramidal cells in the in vitro hippocampal slice. Brain Res 221:117-127.

Sakimura K, Morita T, Kushiya E, Mishina M (1992) Primary structure and expression of the $\gamma 2$ subunit of the glutamate receptor channel selective for kainate. Neuron 8:267-274.

Sommer B, Seeburg PH (1992) Glutamate receptor channels: novel properties and new clones. Trends Pharmacol Sci 13:291-296.

Sommer B, Keinänen K, Verdoorn TA, Wisden W, Burnshev N, Herb A, Köhler M, Takagi T, Sakmann B, Seeburg PH (1990) Flip and Flop: a cell-specific functional switch in glutamate-operated channels of the CNS. Science 249:1580-1585.

Sommer B, Köhler M, Sprengel R, Seeburg PH (1991) RNA editing in brain controls a determinant of ion flow in glutamate-gated channels. Cell 67:11-19.

Sommer B, Burnashev N, Verdoorn TA, Keinänen K, Sakmann B, Seeburg PH (1992) A glutamate receptor channel with high affinity for domoatc and kainate. EMBO J 11:1651-1656.

Somogyi P, Eshhar N, Teichberg VI, Roberts JDB (1990) Subcellular localization of a putative kainate receptor in Bergmann glial cells using a monoclonal antibody in the chick and fish cerebellar cortex. Neuroscience 35:9-30.

Sontheimer H, Kettenmann H, Backus KH, Scachner M (1988) Glutamate opens $\mathrm{Na} / \mathrm{K}$ channels in cultured astrocytes. Glia 1:328-336.

Switzer RC, de Olmos J, Heimer L (1985) Olfactory system. In: The rat nervous system, Vol 1, Forebrain and midbrain (Paxinos G, ed), pp 1-36. New York: Academic.

Takeuchi Y, Takashima M, Katoh Y, Nishikawa T, Takahashi K (1992) $N$-methyl-D-aspartate quisqualate and kainate receptors are all involved in transmission of photic stimulation in the suprachiasmatic nucleus in rats. Brain Res 563:127-131

Ulas J, Monaghan DT, Cotman CW (1990) Kainate receptors in the rat hippocampus: a distribution and time course of changes in response to unilateral lesions of the entorhinal cortex. J Neurosci 10: 2352-2362.

Unnerstall JR, Wamsley JK (1983) Autoradiographic localization of high-affinity $\left[{ }^{3} \mathrm{H}\right]$ kainic acid binding sites in the rat brain. Eur J Pharmacol 86:361-371.

Usowicz MM, Gallo V, Cull-Candy SG (1989) Multiple conductance channels in type- 2 cerebellar astrocytes activated by excitatory amino acids. Nature 339:380-383.

van den Pol AN, Wuarin JP, Dudek FE (1990) Glutamate the dominant excitatory transmitter in neuroendocrine regulation. Science 250:1276-1278.

Wada K, Dechesne CJ, Shimasaki S, King RG, Kusano K, Bounanno A, Hampson DR, Banner C, Wenthold RJ, Nakatani Y (1989) Sequence and expression of a frog brain complementary DNA encoding a kainate-binding protein. Nature 342:684-689.

Wenthold RJ, Yokotani N, Doi K, Wada K (1992) Immunochemical characterization of the non-NMDA glutamate receptor using subunitspecific antibodies. J Biol Chem 267:501-507.

Werner P, Voigt M, Keinänen K, Wisden W, Seeburg PH (1991) Cloning of a putative high-affinity kainate receptor expressed predominantly in hippocampal CA3 cells. Nature 351:742-744.

Westbrook GL, Lothman EW (1983) Cellular and synaptic basis of kainic acid-induced hippocampal epileptiform activity. Brain Res 273:97-109.

Wisden W, Morris BJ, Hunt SP (1991) In situ hybridization with synthetic DNA probes. In: Molecular neurobiology-a practical approach (Chad J, Wheal H, eds), pp 205-225. Oxford UP/IRL.

Wisden W, Laurie DJ, Monyer H, Seeburg PH (1992) The distribution of $13 \mathrm{GABA}_{\mathrm{A}}$ receptor subunit mRNAs in the rat brain. I. telencephalon diencephalon mesencephalon. J Neurosci 12:1040-1062.

Yamazaki M, Araki K, Shibata A, Mishina M (1992) Molecular clon- 
ing of a cDNA encoding a novel member of the mouse glutamate receptor channel family. Biochem Biophys Res Commun 183:886892.
Young AB, Fagg GE (1990) Excitatory amino acid receptors in the brain: membrane binding and receptor autoradiographic approaches. Trends Pharmacol Sci 11:126-133. 